OPEN ACCESS

Edited by:

Amit Kumar Tyagi,

The University of Texas MD Anderson

Cancer Center, USA

Reviewed by:

Shinjini Singh

University of Texas MD Anderson

Cancer Center, USA

Siddhartha Tyagi,

Baylor College of Medicine, USA

*Correspondence:

Paula Bourke

paula.bourke@dit.ie

Specialty section:

This article was submitted to

Food Microbiology,

a section of the journal

Frontiers in Microbiology

Received: 08 January 2016

Accepted: 06 June 2016

Published: 22 June 2016

Citation:

Han L, Ziuzina D, Heslin C, Boehm D,

Patange A, Sango DM,

Valdramidis VP, Cullen PJ and

Bourke P (2016) Controlling Microbial

Safety Challenges of Meat Using High

Voltage Atmospheric Cold Plasma.

Front. Microbiol. 7:977.

doi: 10.3389/fmicb.2016.00977

\section{Controlling Microbial Safety Challenges of Meat Using High Voltage Atmospheric Cold Plasma}

\author{
Lu Han 1, Dana Ziuzina 1, Caitlin Heslin 1, Daniela Boehm 1, Apurva Patange ', \\ David M. Sango ${ }^{2}$, Vasilis P. Valdramidis ${ }^{2}$, Patrick J. Cullen ${ }^{1,3}$ and Paula Bourke ${ }^{1 *}$ \\ 1 School of Food Science and Environmental Health, Dublin Institute of Technology, Dublin, Ireland, ${ }^{2}$ Department of Food \\ Studies and Environmental Health, Faculty of Health Sciences, University of Malta, Msida, Malta, ${ }^{3}$ School of Chemical \\ Engineering, University of New South Wales, Sydney, NSW, Australia
}

Atmospheric cold plasma (ACP) is a non-thermal technology, effective against a wide range of pathogenic microorganisms. Inactivation efficacy results from plasma generated reactive species. These may interact with any organic components in a test matrix including the target microorganism, thus food components may exert a protective effect against the antimicrobial mode of action. The effect of an in-package high voltage ACP process applied in conjunction with common meat processing MAP gas compositions as well as bacteria type and meat model media composition have been investigated to determine the applicability of this technology for decontamination of safety challenges associated with meat products. E. coli, L. monocytogenes, and S. aureus in PBS were undetectable after $60 \mathrm{~s}$ of treatment at $80 \mathrm{kV}_{\mathrm{RMS}}$ in air, while ACP treatment of the contaminated meat model required post-treatment refrigeration to retain antimicrobial effect. The nutritive components in the meat model exerted a protective effect during treatment, where $300 \mathrm{~s}$ ACP exposure yielded a maximum reduction of 1.5 log using a high oxygen atmosphere, whilst using air and high nitrogen atmospheres yielded lower antimicrobial efficacy. Furthermore, an ROS assay was performed to understand the protective effects observed using the meat model. This revealed that nutritive components inhibited penetration of ROS into bacterial cells. This knowledge can assist the optimization of meat decontamination using ACP technology where interactions with all components of the food matrix require evaluation.

Keywords: high voltage plasma, biofilm, beef extract, ROS, Gram negative and positive bacteria

\section{INTRODUCTION}

In the food production chain, meat safety remains a major industrial challenge presented by the emergence of pathogens with low infectious doses, increased virulence, resistance to antibiotics and cross-contamination or recontamination of foods, food contact surfaces and water (Sofos and Geornaras, 2010). Efficient strategies are required to reduce the microbiological safety risks of meat products in tandem with the goal of shelf-life extension.

Modified atmosphere packaging (MAP) is widely used in the food industry to extend shelf-life and avoid contamination and weight loss (Sivertsvik et al., 2002; Kerry et al., 2006). Nitrogen is the 
most widely used gas in MAP, as an inert filler gas either to reduce the proportions of the other gases or to maintain pack shape (Kerry et al., 2006). High oxygen levels (70-80\%) are also used in MAP to reduce microbial growth within the package and preserve the bright red color of fresh meat as well as tenderness and juiciness (Okayama et al., 1995; Lund et al., 2007). Carbon dioxide is also employed for inhibiting bacterial growth (Sivertsvik et al., 2002), and maintaining the red color of meat products. Typically, fresh red meat MAP uses $70 \% \mathrm{O}_{2}+30 \% \mathrm{CO}_{2}$ (Sørheim et al., 1999) and cooked meats are stored in $70 \% \mathrm{~N}_{2}+$ $30 \% \mathrm{CO}_{2}$ (Smiddy et al., 2002).

The efficacy of atmospheric cold plasma (ACP) has been documented for microbial inactivation in a number of food products and the underlying mechanisms of the bactericidal effect have been demonstrated to result partly from cell-lethal reactive species generation (Kayes et al., 2007; Basaran et al., 2008; Klämpfl et al., 2012; Rød et al., 2012; Misra et al., 2014; Ziuzina et al., 2014; Lacombe et al., 2015; Yong et al., 2015). With the emerging range of ACP applications and complexity of system design available, it is important to consider the mechanism of action in relation to critical processing parameters. By discharging in air, the reactive species generated include reactive oxygen species (ROS), reactive nitrogen species (RNS), ultraviolet (UV) radiation, energetic ions and charged particles. ROS are a principal reactive group of species with relatively long half-lives and strong anti-microbial effects (Joshi et al., 2011). These reactive species are believed to cause damage to proteins and nucleic acids and lesions to the cell membrane (Laroussi et al., 2003). However, a number of experimental parameters have been shown to influence the bactericidal efficiency of ACP governing the type and amount of reactive species generated, such as applied voltage (Yun et al., 2010) and treatment time (Miao and Yun, 2011; Ziuzina et al., 2014). Bacterial inactivation also varies depending on the type of bacteria (Montie et al., 2000; Yu et al., 2006; Fernández and Thompson, 2012). Therefore, in the current study, three strains were selected to represent Gram negative and Gram positive bacteria, with bacterial resistance and industrial relevance also considered (Le Loir et al., 2003; Doyle and Erickson, 2006; Denny and McLauchlin, 2008). E. coli NCTC 12900 and S. aureus ATCC 25923 are key food-contaminating pathogens, and have been reported to have strong multi-drug resistance (Brown, 2001; Braoudaki and Hilton, 2004). Their high rate of mutations can lead to cross protective effects against environmental stresses, including oxidative stress. L. monocytogenes has the capability to reproduce at low temperatures with the regulation of cold shock proteins (Bayles et al., 1996), making it a major pathogen of concern in the meat cold chain. Moreover, L. monocytogenes has been shown to be the most resistant on meat surfaces compared with the other key food pathogens (Chorianopoulos, 2012). As many contaminating pathogens in the food processing environment present in resistant biofilm structures attached to biotic or abiotic surfaces, it is important to assess the efficacy of novel decontamination methods against the actual nature of the microbiological challenges presented, thus critically evaluating the potential to reduce risks. Biofilms and attached cells are characterized by an enhanced resistance when compared to their planktonic counterparts for most environmental stresses encountered in food production plants (Giaouris et al., 2014; Bridier et al., 2015).

Although ACP technology is increasingly studied for food decontamination, there are limited studies pertaining to its application on meat products. Therefore, this study provides a detailed investigation of the bactericidal effect of ACP on three key meat-contaminating pathogens using a complex meat model media and elucidates the role of ROS in the disinfection process of ACP. Industry-relevant processing parameters that could interact with ACP efficacy and the mode of action were evaluated by using typical MAP gases for meat products as plasma working gases as well as storage temperature. Therefore, these interactive effects were assessed with regard to ACP efficacy in a meat model to provide insight for the application of ACP for meat decontamination.

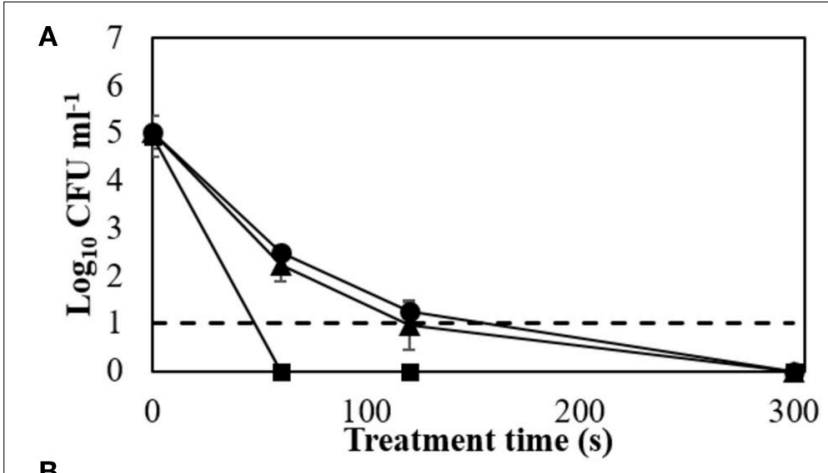

B

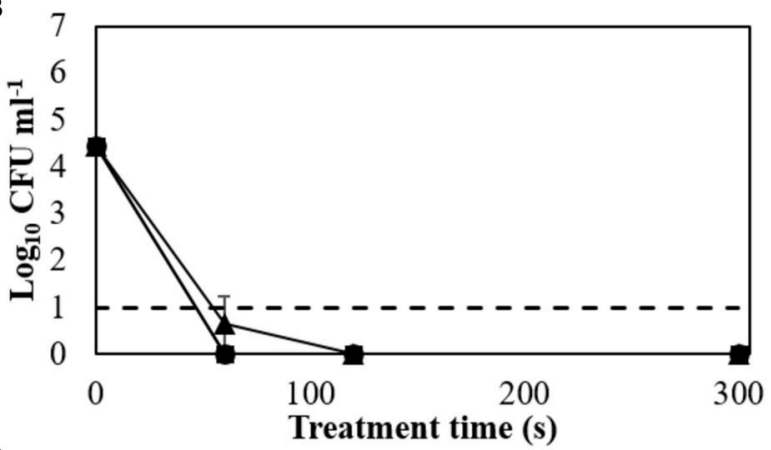

C

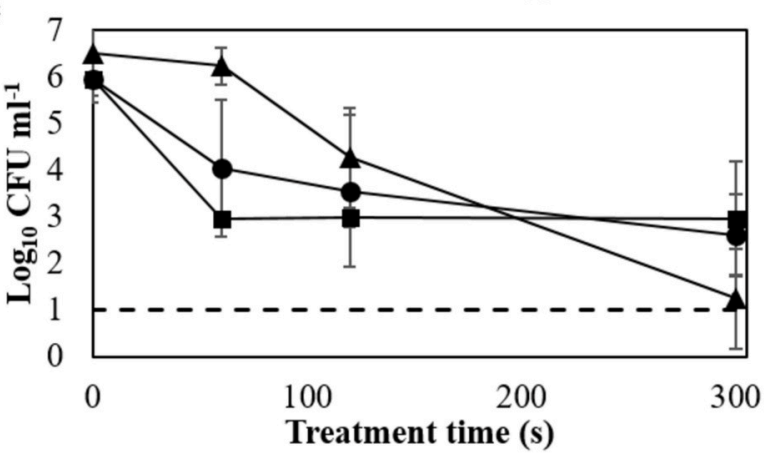

FIGURE 1 | Biofilm inactivation efficacy with applied voltage and treatment time $(24 \mathbf{h}$ storage at room temperature). (A) E. coli NCTC 12900; (B) L. monocytogenes NCTC 11994; (C) S. aureus NCTC 1803. Dotted line: detection limit; $\mathbf{\Lambda}: 60 \mathrm{kV}_{\mathrm{RMS}}$; $\bullet 70 \mathrm{kV}_{\mathrm{RMS}}$; $\mathbf{\square}: 80 \mathrm{kV} \mathrm{RMS}_{\text {. }}$ 


\section{MATERIALS AND METHODS}

\section{Experiment Preparation}

\section{Bacterial Strains and Growth Conditions}

Listeria monocytogenes NCTC 11994 and Staphylococcus aureus NCTC 1803, were obtained from the microbiology stock culture of the School of Food Science and Environmental Health, Dublin Institute of Technology. Escherichia coli NCTC 12900, (nontoxigenic O157:H7) was obtained from the National Collection of Type Cultures of the Health Protection Agency (HPA, UK). Strains were selected to present both Gram positive and Gram negative foodborne challenges and to facilitate comparison with other studies. Strains were maintained as frozen stocks at $-70^{\circ} \mathrm{C}$ in the form of protective beads, which were plated onto tryptic soy agar (TSA, Scharlau Chemie, Barcelona, Spain) and incubated overnight at $37^{\circ} \mathrm{C}$ to obtain single colonies before storage at $4^{\circ} \mathrm{C}$.

\section{Preparation of Planktonic Bacterial Cell Suspensions}

Cells were grown overnight $(18 \mathrm{~h})$ by inoculating an isolated colony of each bacteria in $12 \%$ Beef Extract (BE, Scharlau Chemie, Barcelona, Spain) at $37^{\circ} \mathrm{C}$. Cells were harvested by centrifugation at $10,000 \mathrm{rpm}$ for $10 \mathrm{~min}$. The cell pellet was washed twice with sterile phosphate buffered saline (PBS, Oxoid LTD, UK). The pellet was re-suspended in PBS and the bacterial density was determined by measuring the absorbance at $550 \mathrm{~nm}$ using McFarland standard (BioMérieux, Marcyl'Étoile, France). Finally, cell suspensions with a concentration of $10^{7} \mathrm{CFU} \mathrm{ml} \mathrm{m}^{-1}$ were prepared in $\mathrm{PBS}, 3$ or $12 \% \mathrm{BE}$, and then used for inactivation of bacteria in planktonic state and ROS studies. Prior to ACP treatment, aliquots of $100 \mu \mathrm{l}$ per well cell suspensions in PBS, 3 or $12 \% \mathrm{BE}$ were dispensed into the wells of a microtiter plate for planktonic samples.

\section{Biofilm Formation}

Bacterial biofilms were produced by adding $200 \mu \mathrm{l}$ of $12 \% \mathrm{BE}$ bacterial suspension with a cell density of $1.0 \times 10^{7} \mathrm{CFU} \mathrm{m}{ }^{-1}$ into the wells of 96 well microtiter plates (Sarstedt, Nümbrecht, Germany).

The plates were incubated at $37^{\circ} \mathrm{C}$ for $48 \mathrm{~h}$. After $24 \mathrm{~h}$ of incubation the supernatant from each well was replaced with fresh BE, with further incubation for $24 \mathrm{~h}$. After incubation, the $\mathrm{BE}$ containing the suspended bacterial cells was removed and wells rinsed three times with sterile deionized water and dried, leaving only bacterial biofilms for further investigation. Negative controls were obtained by using BE without inoculation. Prior to each experiment, the microtiter plates containing biofilms were air dried for $60 \mathrm{~min}$.

\section{ACP System Configuration}

The DBD ACP system used in this study has been described by Han et al. (2015) and its electrical properties has been reported by Moiseev et al. (2014). The system was operated at high voltage levels of 60,70 , and $80 \mathrm{kV}_{\mathrm{RMS}}$ under atmospheric pressure. A polypropylene container, which acted as a sample holder and a dielectric barrier, was placed between the two perspex dielectric layers. The overall distance between the two electrodes was kept constant $(3 \mathrm{~cm})$ for all experiments.

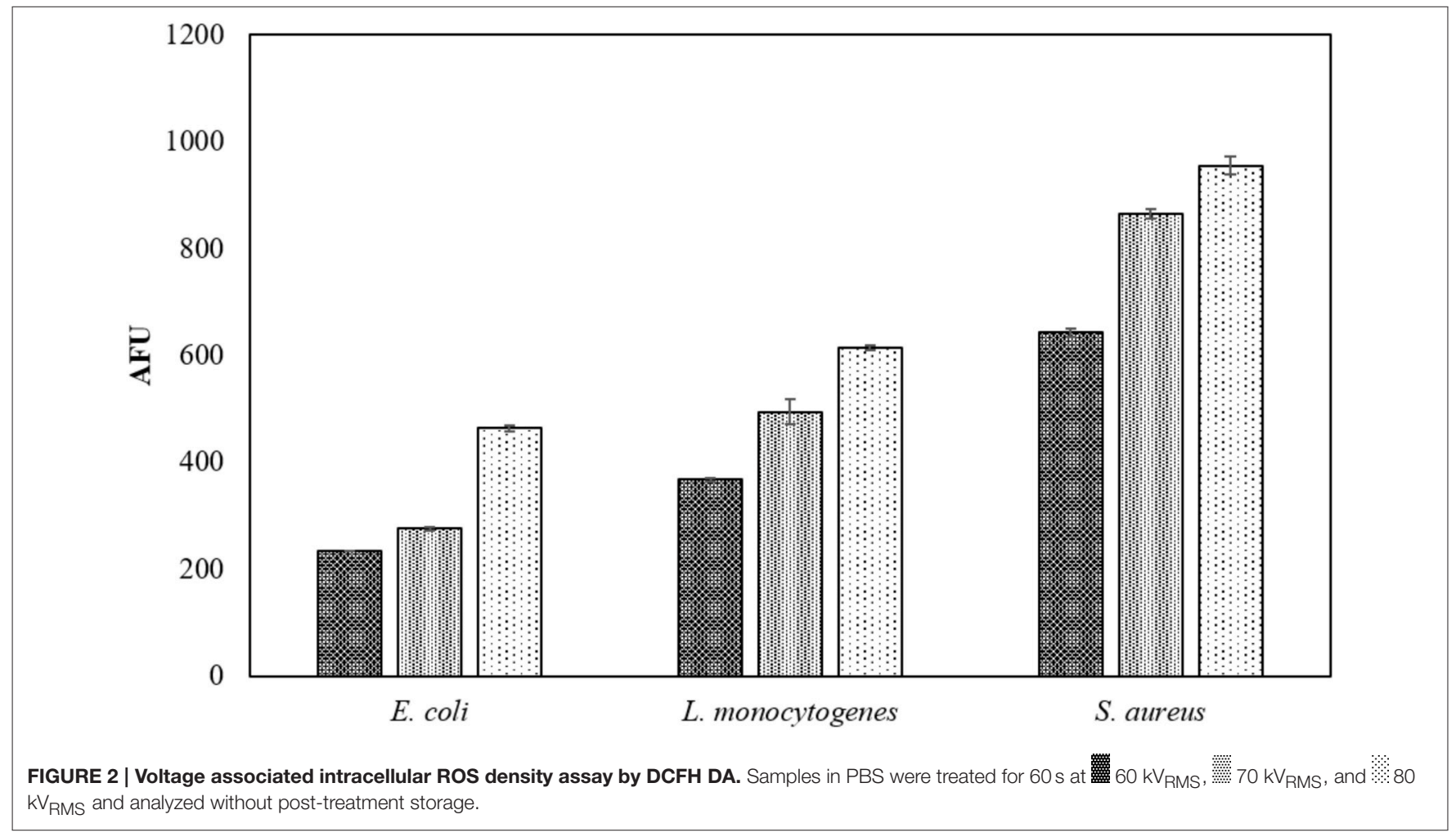




\section{ACP Treatment Time, Voltage Level, and Post-Treatment Storage}

Each microtiter plate was placed in the center of the rigid polypropylene plastic container, which was positioned directly between the electrodes within the plasma discharge for direct plasma treatment. The distance between the sample and top electrode was $20 \mathrm{~mm}$. Each container was sealed with a high barrier polypropylene bag (Cryovac, B2630, USA). Air (gas 2) was used as the working gas for generation of ACP. For the gas mixtures of $30 \% \mathrm{CO}_{2}+70 \% \mathrm{~N}_{2}$ (gas 1) and $30 \% \mathrm{CO}_{2}+70 \%$ $\mathrm{O}_{2}$ (gas 3), the required working gas was filled into a sealed and pre-vacuumed package using a flow regulator at a controlled flow rate of $0.5 \mathrm{~L} \mathrm{~min} \mathrm{~m}^{-1}$ for $1 \mathrm{~min}$. To assess the effect of voltage on inactivation efficiency, bacterial samples were treated with either 60,70 , or $80 \mathrm{kV}_{\mathrm{RMS}}$, over a range of treatment times (60, 120 , or 300 s). Bacterial samples in PBS were exposed to shorter treatment times $(15,30$, or $60 \mathrm{~s})$. After treatment, samples were stored at either room temperature or $4^{\circ} \mathrm{C}$ for $24 \mathrm{~h}$ to assess the effect of ACP generated reactive species during post-treatment storage time (Han et al., 2014). All experiments were carried out in duplicate and replicated twice.

\section{Post-Treatment Analysis \\ Ozone Measurements}

Ozone concentrations generated inside the sealed packages were measured using GASTEC gas tube detectors (Product \#

TABLE 1 | E. coli NCTC12900 planktonic inactivation efficacy at $80 \mathrm{kV}_{\mathrm{RMS}}$ with different media and post-treatment storage conditions.

\begin{tabular}{|c|c|c|c|c|c|}
\hline \multirow[t]{3}{*}{ Media } & \multirow{3}{*}{$\begin{array}{c}\text { Plasma treatment } \\
\text { time (s) }\end{array}$} & \multicolumn{4}{|c|}{ Storage condition } \\
\hline & & \multicolumn{2}{|c|}{$4^{\circ} \mathrm{C}$ storage } & \multicolumn{2}{|c|}{ RT storage } \\
\hline & & $\begin{array}{l}\text { Cell density } \\
\left(\log _{10} \text { CFU }\right. \\
\mathrm{ml}^{-1} \text { ) }\end{array}$ & SD $^{*}$ & $\begin{array}{c}\text { Cell density } \\
\left(\log _{10} \text { CFU }\right. \\
\mathrm{ml}^{-1} \text { ) }\end{array}$ & $S^{*}$ \\
\hline \multirow[t]{5}{*}{$3 \% \mathrm{BE}$} & $C^{1^{\star}}$ & $7.11^{\mathrm{ab}}$ & 0.06 & $6.96^{a}$ & 0.19 \\
\hline & $c^{2^{*}}$ & $6.95^{b c}$ & 0.11 & $9.18^{b}$ & 0.16 \\
\hline & 60 & $7.35^{\mathrm{b}}$ & 0.25 & $9.11^{b}$ & 0.13 \\
\hline & 120 & $6.73^{\mathrm{C}}$ & 0.13 & $9.15^{\mathrm{b}}$ & 0.13 \\
\hline & 300 & $6.06^{d}$ & 0.15 & $8.41^{\mathrm{C}}$ & 0.55 \\
\hline \multirow[t]{5}{*}{$12 \% \mathrm{BE}$} & $C^{1^{\star}}$ & $7.13^{\mathrm{ab}}$ & 0.16 & $7.02^{a}$ & 0.29 \\
\hline & $\mathrm{C}^{2^{*}}$ & $7.18^{\mathrm{ab}}$ & 0.21 & $9.39^{d}$ & 0.07 \\
\hline & 60 & $7.32^{\mathrm{b}}$ & 0.04 & $9.47^{d}$ & 0.17 \\
\hline & 120 & $7.12^{\mathrm{C}}$ & 0.68 & $9.33^{b d}$ & 0.26 \\
\hline & 300 & $5.79^{d}$ & 0.92 & $9.35^{d}$ & 0.36 \\
\hline \multirow[t]{5}{*}{ PBS } & $C^{1^{*}}$ & $7.18^{\mathrm{ab}}$ & 0.09 & $6.94^{a}$ & 0.19 \\
\hline & $C^{2^{*}}$ & $6.94^{b c}$ & 0.09 & $6.90^{\mathrm{a}}$ & 0.00 \\
\hline & 60 & $N D^{*} \mathrm{e}$ & - & $N D^{*} \mathrm{e}$ & - \\
\hline & 120 & $N D^{*}$ & - & $N D^{*}$ & - \\
\hline & 300 & $N D^{*} \mathrm{e}$ & - & $N D^{*} \mathrm{e}$ & - \\
\hline
\end{tabular}

$S D^{*}$, standard deviation; $N D^{*}$, non-detectable; $C^{1^{*}}$, Control without storage; $C^{2^{*}}$, Control with storage. Different letters indicate a significant difference at the 0.05 level between media and treatment times.
18M, Gastec Corporation, Kanagawa, Japan) immediately after treatment and also after $24 \mathrm{~h}$ storage.

\section{Detection of Reactive Oxygen Species after ACP Treatment}

DCFH-DA $\left(2^{\prime}, 7^{\prime}\right.$-dichlorodihydrofluorescein diacetate $)$ is a cellular assay probe widely used for fluorescence detection of intracellular ROS (Gomes et al., 2005).

After ACP treatment and storage, cells were incubated with DCFH-DA (Sigma-Aldrich, USA) at a final concentration of $5 \mu \mathrm{M}$ in PBS for $15 \mathrm{~min}$ at $37^{\circ} \mathrm{C}$. Two hundred micro liter aliquots of each sample were transferred into 96 well fluorescence microplate wells (Fisher Scientific, UK) and measured by a Synergy ${ }^{\mathrm{TM}}$ HT Multi-Mode Microplate Reader (BioTek Instruments Inc.) at excitation and emission wave lengths of 485 and $525 \mathrm{~nm}$ (Joshi et al., 2011). However, extracellular reactive species may have interference and result in higher fluorescence signals (Gomes et al., 2005). The results represent total ROS effect after discharging. Fluorescence data were obtained by subtracting the background fluorescence of the respective untreated control cells, due to the much higher background from BE than PBS. These data represent the ROS concentrations generated after ACP treatment expressed as arbitrary fluorescence units (AFU).

\section{Microbiological Analysis}

To assess effects on planktonic bacterial populations, dilutions were prepared using maximum recovery diluent (MRD, Scharlau

TABLE 2 | L. monocytogenes NCTC11994 planktonic inactivation efficacy at $80 \mathrm{kV}_{\mathrm{RMS}}$ with different media and post-treatment storage conditions.

\begin{tabular}{|c|c|c|c|c|c|}
\hline \multirow[t]{3}{*}{ Media } & \multirow{3}{*}{$\begin{array}{c}\text { Plasma treatment } \\
\text { time (s) }\end{array}$} & \multicolumn{4}{|c|}{ Storage condition } \\
\hline & & \multicolumn{2}{|c|}{$4^{\circ} \mathrm{C}$ storage } & \multicolumn{2}{|c|}{ RT storage } \\
\hline & & $\begin{array}{c}\text { Cell density } \\
\left(\log _{10} \text { CFU }\right. \\
\left.\mathrm{ml}^{-1}\right)\end{array}$ & $S^{*}$ & $\begin{array}{l}\text { Cell density } \\
\left(\log _{10} \text { CFU }\right. \\
\left.\mathrm{ml}^{-1}\right)\end{array}$ & $S^{*}$ \\
\hline \multirow[t]{5}{*}{$3 \% \mathrm{BE}$} & $\mathrm{C}^{1^{*}}$ & $7.23^{a}$ & 0.06 & $7.23^{a}$ & 0.06 \\
\hline & $C^{2^{*}}$ & $7.35^{\mathrm{a}}$ & 0.01 & $9.10^{\mathrm{b}}$ & 0.03 \\
\hline & 60 & $7.23^{\mathrm{a}}$ & 0.14 & $8.90^{\mathrm{b}}$ & 0.09 \\
\hline & 120 & $6.70^{\mathrm{b}}$ & 0.23 & $8.60^{\mathrm{b}}$ & 0.09 \\
\hline & 300 & $5.07^{c}$ & 0.35 & $7.20^{\mathrm{a}}$ & 0.84 \\
\hline \multirow[t]{5}{*}{$12 \% \mathrm{BE}$} & $C^{1^{*}}$ & $7.26^{a}$ & 0.10 & $7.26^{a}$ & 0.10 \\
\hline & $C^{2^{*}}$ & $7.43^{d}$ & 0.02 & $9.63^{C}$ & 0.05 \\
\hline & 60 & $7.32^{\mathrm{d}}$ & 0.19 & $9.00^{d}$ & 0.07 \\
\hline & 120 & $7.54^{d}$ & 0.19 & $9.16^{\mathrm{cd}}$ & 0.08 \\
\hline & 300 & $6.18^{e}$ & 0.19 & $7.93^{e}$ & 0.49 \\
\hline \multirow[t]{5}{*}{ PBS } & $C^{1^{*}}$ & $7.29^{a}$ & 0.04 & $7.29^{a}$ & 0.04 \\
\hline & $C^{2^{*}}$ & $7.08^{9}$ & 0.01 & $6.84^{\dagger}$ & 0.03 \\
\hline & 60 & $N D^{* h}$ & - & $N D^{*} g$ & - \\
\hline & 120 & $N D^{\star h}$ & - & $N D^{*} g$ & - \\
\hline & 300 & $N D^{*} h$ & - & $N D^{*} \mathrm{~g}$ & - \\
\hline
\end{tabular}

$S D^{*}$, standard deviation; $N D^{*}$, non-detectable; $C^{1^{*}}$, Control without storage; $C^{2^{*}}$, Control with storage. Different letters indicate a significant difference at the 0.05 level between media and treatment times. 
Chemie, Barcelona, Spain), which were further plated on TSA. In order to obtain low microbial detection limits, $1 \mathrm{ml}$ and $0.1 \mathrm{ml}$ of the treated sample was spread onto TSA plates as described by EN ISO 11290-2 method (ISO 11290-2, 1998). The limit of detection was $1.0 \log _{10} \mathrm{CFU} \mathrm{ml}{ }^{-1}$. Plates were incubated at $37^{\circ} \mathrm{C}$ for $24 \mathrm{~h}$ and colony forming units were counted. Any plates with no growth were incubated for up to $72 \mathrm{~h}$ and checked for the presence of colonies every $24 \mathrm{~h}$. Results are reported in $\log _{10} \mathrm{CFU}$ $\mathrm{ml}^{-1}$ units.

To quantify the effects of ACP treatment on biofilms, PBS $(100 \mu \mathrm{l})$ was added into the wells containing biofilms. The 96 well plate was then sonicated for $5 \mathrm{~min}$ to detach the bacterial cells into the solution using a water bath sonicator (Bransonic 5510E-MT, USA, Mexico). PBS cell suspensions from each well for corresponding samples were mixed to obtain an average surviving bacterial population, serially diluted in MRD and surface plated on TSA.

\section{Modeling Microbial Recovery}

Two hundred micro liter aliquots of bacterial suspensions in 3\% BE were pipetted into 96 well microtiter plates. The initial cell density was $1.0 \times 10^{7} \mathrm{CFU} \mathrm{ml}{ }^{-1}$ with four decimal dilutions of the suspensions performed in the microtiter plate. Samples were ACP treated for 60,120 , and $300 \mathrm{~s}$ and stored at $4^{\circ} \mathrm{C}$ for $24 \mathrm{~h}$ post-treatment. Twenty micro liter aliquots from each well were analyzed using plate count. The microtiter plates

TABLE 3 | S. aureus NCTC1803 planktonic inactivation efficacy at 80 $\mathrm{kV}_{\mathrm{RMS}}$ with different media and post-treatment storage conditions.

\begin{tabular}{|c|c|c|c|c|c|}
\hline \multirow[t]{3}{*}{ Media } & \multirow{3}{*}{$\begin{array}{c}\text { Plasma treatment } \\
\text { time (s) }\end{array}$} & \multicolumn{4}{|c|}{ Storage condition } \\
\hline & & \multicolumn{2}{|c|}{$4^{\circ} \mathrm{C}$ storage } & \multicolumn{2}{|c|}{ RT storage } \\
\hline & & $\begin{array}{l}\text { Cell density } \\
\left(\text { Log }_{10} \text { CFU }\right. \\
\mathrm{ml}^{-1} \text { ) }\end{array}$ & $S^{*}$ & $\begin{array}{c}\text { Cell density } \\
\left(\log _{10} \text { CFU }\right. \\
\mathrm{ml}^{-1} \text { ) }\end{array}$ & $\mathrm{SD}^{*}$ \\
\hline \multirow[t]{5}{*}{$3 \% \mathrm{BE}$} & $C^{1^{*}}$ & $7.29^{a}$ & 0.04 & $6.03^{a}$ & 0.46 \\
\hline & $c^{2^{*}}$ & $6.63^{b}$ & 0.26 & $8.87^{b}$ & 0.01 \\
\hline & 60 & $5.71^{\mathrm{C}}$ & 0.34 & $8.08^{b c}$ & 0.17 \\
\hline & 120 & $5.79^{c}$ & 0.17 & $7.98^{\mathrm{C}}$ & 0.31 \\
\hline & 300 & $5.02^{d}$ & 0.33 & $7.03^{d}$ & 0.58 \\
\hline \multirow[t]{5}{*}{$12 \% \mathrm{BE}$} & $C^{1^{*}}$ & $7.17^{e}$ & 0.06 & $6.30^{a}$ & 0.14 \\
\hline & $c^{2^{*}}$ & $6.52^{\mathrm{b}}$ & 0.09 & $9.01^{e}$ & 0.14 \\
\hline & 60 & $6.33^{f}$ & 0.33 & $8.83^{e f}$ & 0.06 \\
\hline & 120 & $6.35^{f}$ & 0.22 & $8.76^{f}$ & 0.07 \\
\hline & 300 & $5.76^{9}$ & 0.05 & $8.43^{9}$ & 0.09 \\
\hline \multirow[t]{5}{*}{ PBS } & $C^{1^{*}}$ & $7.40^{\text {ah }}$ & 0.07 & $6.41^{a}$ & 0.18 \\
\hline & $c^{2^{*}}$ & $6.37^{\mathrm{b}}$ & 0.01 & $6.52^{\mathrm{a}}$ & 0.19 \\
\hline & 60 & $N D^{*_{i}}$ & - & $N D^{* h}$ & - \\
\hline & 120 & $N D^{*_{i}}$ & - & $N D^{* h}$ & - \\
\hline & 300 & $N D^{*_{i}}$ & - & $N D^{* h}$ & - \\
\hline
\end{tabular}

$S D^{*}$, standard deviation; $N D^{*}$, non-detectable; $C^{1^{*}}$, Control without storage; $C^{2^{*}}$, Control with storage. Different letters indicate a significant difference at the 0.05 level between media and treatment times. were then placed in a microplate spectrophotometer (ELx808, BioTek Instruments Inc., U.S.A.) set at $37^{\circ} \mathrm{C}$. Absorbance readings were taken at $600 \mathrm{~nm}$ every $30 \mathrm{~min}$ for $48 \mathrm{~h}$. The OD values were used to quantify the growth rate, $\mu_{\max }$ and the lag phase, $\lambda$, of all the bacteria studies using the following equation (Cuppers and Smelt, 1993; Biesta-Peters et al., 2010):

$$
\operatorname{TTD}_{i}=\lambda+\frac{1}{\mu_{\max }} \cdot \log \left(\frac{N_{\text {turb }}}{N_{i}}\right)
$$

where $T T D_{i}$, is time to detection (h) of the inoculum level $i$, chosen as the time at which the sample in the well reaches an $\mathrm{OD}_{600}$ of 0.2 (Biesta-Peters et al., 2010), $\lambda$ is the duration of the lag phase (h), $N_{\text {turb }}$ is the number of bacteria per ml (CFU $\mathrm{ml}^{-1}$ ) at which an $\mathrm{OD}_{600}$ of 0.2 is observed, $N_{i}$ is the number of organisms per $\mathrm{ml}$ of the inoculum at time zero, and $\mu_{\max }$ is the maximum specific growth rate $\left(\mathrm{h}^{-1}\right) . N_{\text {turb }}$ was determined through separate experiments. The goodness of fit of these curves was validated experimentally. The kinetic parameters $\left(\mu_{\max }\right.$ and $\lambda$ ) were calculated by performing a regression analysis on the data correlating TTD with $\log \left(N_{\text {turb }} / N_{0}\right)$ using equation 1 for each replicate separately (Millan Sango et al., 2015).

\section{Statistical Analysis}

Results were analyzed using SPSS 22.0 (SPSS Inc., Chicago, U.S.A.). Means were compared using analysis of variance (ANOVA) using Fisher's Least Significant Difference-LSD at the 0.05 level.

\section{RESULTS \\ Effect of Applied Voltage on ACP Inactivation Efficacy}

The effect of a range of high voltage levels $\left(60,70\right.$, and $\left.80 \mathrm{kV}_{\mathrm{RMS}}\right)$ on ACP efficacy against key meat pathogens grown as biofilms using a meat model medium was investigated (Figure 1).

Treatment at 60 or $70 \mathrm{kV}_{\mathrm{RMS}}$ had similar inactivation effects for $E$. coli with approximately 2 log cycles remaining after $60 \mathrm{~s}$ of ACP exposure. However, complete inactivation was obtained after $60 \mathrm{~s}$ of treatment at $80 \mathrm{kV}_{\mathrm{RMS}}$ (Figure 1A). L. monocytogenes biofilm showed greater susceptibility, where similar inactivation patterns were found for 60,70 , and $80 \mathrm{kV}_{\mathrm{RMS}}$ treatment, with non-detectable cell concentrations after $60 \mathrm{~s}$ (Figure 1B).

Extending treatment time from 120 to $300 \mathrm{~s}$ at 60 and $70 \mathrm{kV}_{\mathrm{RMS}}$ reduced $S$. aureus biofilms significantly. After $60 \mathrm{~s}$ treatment at $80 \mathrm{kV}_{\mathrm{RMS}}$, bacterial concentrations were reduced to $2.96 \pm 0.14 \log$ cycles. However, extending the exposure time at $80 \mathrm{kV}_{\mathrm{RMS}}$ did not lead to further significant reductions in population density (Figure 1C).

The fluorescent probe used for measuring ROS is more accurate when using planktonic cells in PBS and thus the positive effect of voltage on the ROS densities in liquid samples is shown in Figure 2. Fluorescence levels gradually increased with applied voltages of 60,70 , and $80 \mathrm{kV}_{\mathrm{RMS}}$. 


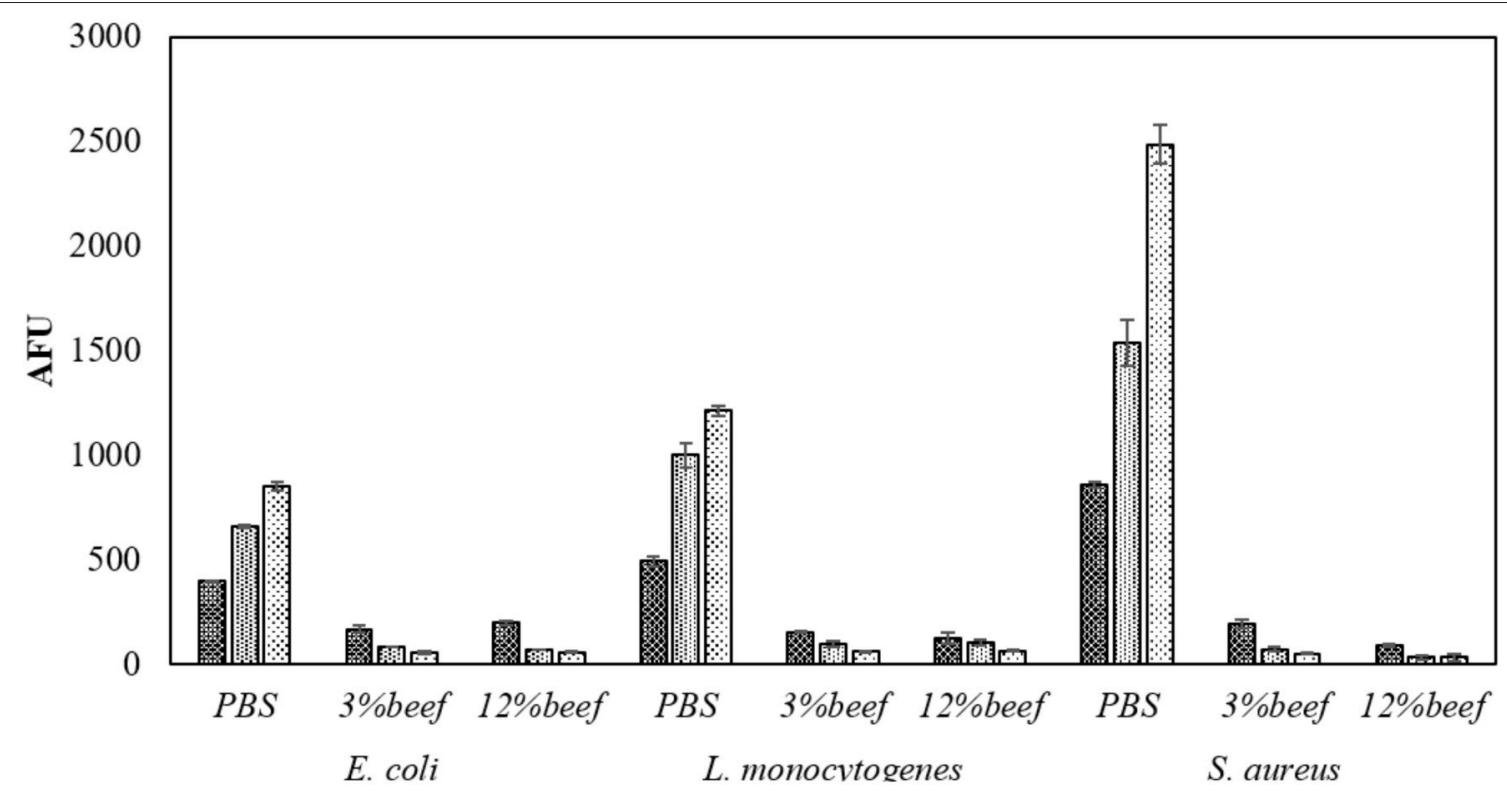

FIGURE 3 | Media associated intracellular ROS density assay by DCFH DA. Samples in PBS, 3\% BE and 12\% BE were treated for $60 \mathrm{~s}$, 带 $120 \mathrm{~s}$, and $300 \mathrm{~s}$ at $80 \mathrm{kV}$ RMS and analyzed without post-treatment storage.

\section{Effect of Media and Post-Treatment Storage Temperature on ACP Inactivation Efficacy}

Tables 1-3 show the inactivation efficacy of ACP treatment at 80 $\mathrm{kV}_{\mathrm{RMS}}$ against planktonic cells of E. coli, L. monocytogenes, and $S$. aureus, respectively, as a function of treatment time, media composition, and storage temperature conditions.

In PBS where there was little or no media based interference with the reactive species generated, all populations were reduced to non-detectable levels by $60 \mathrm{~s}$ treatments at both storage temperatures. Inactivation in both 3 and $12 \%$ BE was strongly reduced compared to treatment in PBS and required extended treatment times of 120 and $300 \mathrm{~s}$ to achieve any significant effects, which did not exceed 2 log total reduction (Tables 13). In Figure 3, the detected ROS levels from BE at either concentration were much lower than those from PBS and actually decreased with treatment time. Again, S. aureus suspensions had the highest ROS density among all three strains for all treatment times, and L. monocytogenes had slightly higher levels than E. coli.

At room temperature, control groups of all bacteria in $\mathrm{BE}$ increased by 1.87-2.84 log cycles during $24 \mathrm{~h}$ storage and populations in treated samples exceeded the starting cell concentrations after storage (Tables 1-3). However, at $4^{\circ} \mathrm{C}$ storage, no significant growth of bacteria occurred during the storage period and the inactivation achieved with ACP treatment was maintained.

\section{Modeling Microbial Recovery}

$N_{\text {turb }}$ of three strains were determined and tabulated in Table 4 before ACP treatment. Table 5 represents the results of $\mu_{\max }$ with different ACP treatment times for the three bacteria. An overall
TABLE 4 | $N_{\text {turb }}$ from the calibration curves.

\begin{tabular}{lcc}
\hline Microorganism & $\begin{array}{c}\boldsymbol{N}_{\text {turb }} \text { from } \\
\text { calibration curve }\end{array}$ & $\begin{array}{c}\boldsymbol{N}_{\text {turb }} \\
\text { experimental data }\end{array}$ \\
\hline E. coli NCTC 12900 & 7.89 & 7.05 \\
L. monocytogenes NCTC 11994 & 8.39 & 8.62 \\
S. aureus ATCC 1803 & 8.13 & 7.04 \\
\hline
\end{tabular}

decrease of the bacterial growth rate was observed for extended treatment times.

\section{Effect of Different Media and Gas Composition on ACP Inactivation Efficacy}

As before, the inactivation efficacy increased with treatment time in PBS (Table 6), where all strains were undetectable after $60 \mathrm{~s}$ treatment in air. E. coli and L. monocytogenes were reduced below the detection limit after $30 \mathrm{~s}$ treatment in high oxygen gases, which was achieved with $60 \mathrm{~s}$ treatment in air. S. aureus had the highest resistance to ACP and was reduced from $6.88 \pm 0.04 \log$ cycles to $5.74 \pm 0.19,2.51 \pm 0.45$ and $1.71 \pm 0.36 \mathrm{log}$ cycles in $30 \% \mathrm{CO}_{2}+70 \% \mathrm{~N}_{2}$, air and $30 \% \mathrm{CO}_{2}+70 \% \mathrm{O}_{2}$ respectively after 30 s treatment (Table 6, $p<0.05$ ).

The beef extract maintained a strong protective effect against ACP efficacy in the modified atmospheres. One minute of ACP treatment resulted in up to 7 log reduction in PBS samples, while a maximum reduction of $2.2 \mathrm{log}$ was obtained with $\mathrm{BE}$ samples and extended treatment times of $300 \mathrm{~s}$ (Tables 6, 7). In this study, in-package ozone levels were measured as an indicator of the overall ROS concentration in gas phase. Both ozone levels and detected ROS concentrations in liquid were dependent on the gas composition, where ROS were barely detected in $30 \% \mathrm{CO}_{2}+70 \%$ 
$\mathrm{N}_{2}$ samples and no ozone was measured inside these packages (Figure 4, Table 8).

\section{DISCUSSION}

In order to evaluate the optimal conditions for antimicrobial efficacy of ACP treatment, process and system parameters

TABLE 5 | Kinetic parameters of the bacteria after different ACP treatment times at $80 \mathrm{kV}_{R M S}$ and $24 \mathrm{~h}$ storage at $4^{\circ} \mathrm{C}$.

\begin{tabular}{lccc}
\hline Microorganisms & Treatment time (s) & $\boldsymbol{\mu}_{\max }\left(\mathbf{h}^{\mathbf{- 1}}\right)$ & $\mathbf{S D}^{*}$ \\
\hline E. coli NCTC 12900 & $\mathrm{C}$ & 1.26 & 0.55 \\
& 60 & 1.09 & 0.23 \\
& 120 & 0.59 & 0.20 \\
& 300 & 0.21 & 0.04 \\
\hline L. monocytogenes NCTC 11994 & $\mathrm{C}$ & 0.35 & 0.07 \\
& 60 & 0.17 & 0.09 \\
& 120 & 0.28 & 0.30 \\
S. aureus NCTC 1803 & 300 & 0.17 & 0.01 \\
& $\mathrm{C}$ & 0.86 & 0.29 \\
& 60 & 0.46 & 0.16 \\
& 120 & 0.46 & 0.11 \\
& 300 & 0.31 & 0.34 \\
\hline
\end{tabular}

$S D^{*}$, standard deviation. including applied voltages, treatment time and MAP gas mixtures were investigated in tandem with storage conditions and treatment media reflecting real food complexity.

Increasing voltage levels generally resulted in higher inactivation of biofilms, reaching non-detectable levels in some cases (Figures 1A-C). The applied power determines the input energy of discharge, which leads to different amounts of reactive species generated and inactivation levels (Tang et al., 2011; Pankaj et al., 2013). The detected ROS levels increased along with the applied voltages, indicating the reason for faster inactivation at higher voltages (Figure 2). Treatment time also governs input energy of ACP and influences microbial inactivation by generating time-dependent amounts of reactive species. Similar trends were observed in previous studies on the inactivation efficacy correlated to voltage and treatment time (Fernández et al., 2013; Han et al., 2014; Niemira et al., 2014). These results confirmed that high voltage ACP significantly reduced key meat pathogens in a nutrient rich environment and in an attached state, and that when the highest voltage level was applied, there was no further advantage incurred with extending duration of treatment beyond $60 \mathrm{~s}$, which is of relevance when retention of other fresh quality characteristics is required (Tables 1-3).

Three pathogens of concern were evaluated in this study, with interesting trends emerging. Some comparison of ACP inactivation effects on different bacteria has been previously reported (Ermolaeva et al., 2011; Klämpfl et al., 2012; Liang et al., 2012). In the current study, the three bacteria displayed distinct differences in the detected ROS concentrations in PBS suspensions, although similar inactivation levels were

TABLE 6 | Planktonic inactivation efficacy at $80 \mathrm{kV}_{\mathrm{RMS}}$ in MAP gases in PBS with $24 \mathrm{~h}$ storage at $4^{\circ} \mathrm{C}$.

\begin{tabular}{|c|c|c|c|c|c|c|c|}
\hline \multirow[t]{2}{*}{ Gases } & \multirow{2}{*}{$\begin{array}{l}\text { Plasma treatment } \\
\text { time (s) }\end{array}$} & \multicolumn{6}{|c|}{ Microorganisms } \\
\hline & & \multicolumn{2}{|l|}{ E. coli NCTC12900 } & \multicolumn{2}{|l|}{ L. monocytogenes NCTC11994 } & \multicolumn{2}{|l|}{ S. aureus NCTC1803 } \\
\hline \multirow[t]{4}{*}{1} & $C^{1^{*}}$ & $7.16^{a}$ & 0.07 & $7.51^{a}$ & 0.11 & $6.88^{a}$ & 0.04 \\
\hline & $c^{2^{*}}$ & $6.57^{b}$ & 0.24 & $6.93^{b}$ & 0.40 & $6.52^{\mathrm{b}}$ & 0.10 \\
\hline & 30 & $5.87^{d}$ & 0.03 & $5.83^{d}$ & 0.06 & $5.74^{d}$ & 0.19 \\
\hline & 60 & $5.74^{d}$ & 0.05 & $5.21^{e}$ & 0.10 & $5.39^{e}$ & 0.10 \\
\hline \multirow[t]{3}{*}{2} & $\mathrm{C}^{1^{*}}$ & $7.16^{a}$ & 0.07 & $7.51^{a}$ & 0.11 & $6.88^{a}$ & 0.04 \\
\hline & $C^{2^{*}}$ & $6.99^{a b}$ & 0.07 & $6.93^{b}$ & 0.40 & $6.78^{a}$ & 0.08 \\
\hline & 15 & $6.50^{b}$ & 0.23 & $6.55^{b c}$ & 0.13 & $5.47^{\mathrm{C}}$ & 0.40 \\
\hline & $C^{2^{*}}$ & $6.81^{\mathrm{ab}}$ & 0.10 & $6.05^{\mathrm{h}}$ & 0.17 & $6.30^{\mathrm{a}}$ & 0.08 \\
\hline & 15 & $6.57^{b}$ & 0.08 & $5.79^{d}$ & 0.02 & $5.11^{\mathrm{C}}$ & 1.08 \\
\hline & 30 & $N D^{* f}$ & - & $N D^{*} g$ & - & $1.71^{\mathrm{h}}$ & 0.36 \\
\hline & 60 & $N D^{* f}$ & - & ND*g & - & $N D^{*} \mathrm{~g}$ & - \\
\hline
\end{tabular}

$S D^{*}$, standard deviation; ND*, non-detectable; $C^{1^{*}}$, Control without storage; $C^{2^{*}}$, Control with storage. Different letters indicate a significant difference at the 0.05 level between gas mix and treatment times. Gases: $130 \% \mathrm{CO}_{2}+70 \% \mathrm{~N}_{2} ; 2$ Air; $330 \% \mathrm{CO}_{2}+70 \% \mathrm{O}_{2}$. 
TABLE 7 | Planktonic inactivation efficacy at $80 \mathrm{kV}_{\mathrm{RMS}}$ in MAP gases in BE with $24 \mathrm{~h}$ storage at $4^{\circ} \mathrm{C}$.

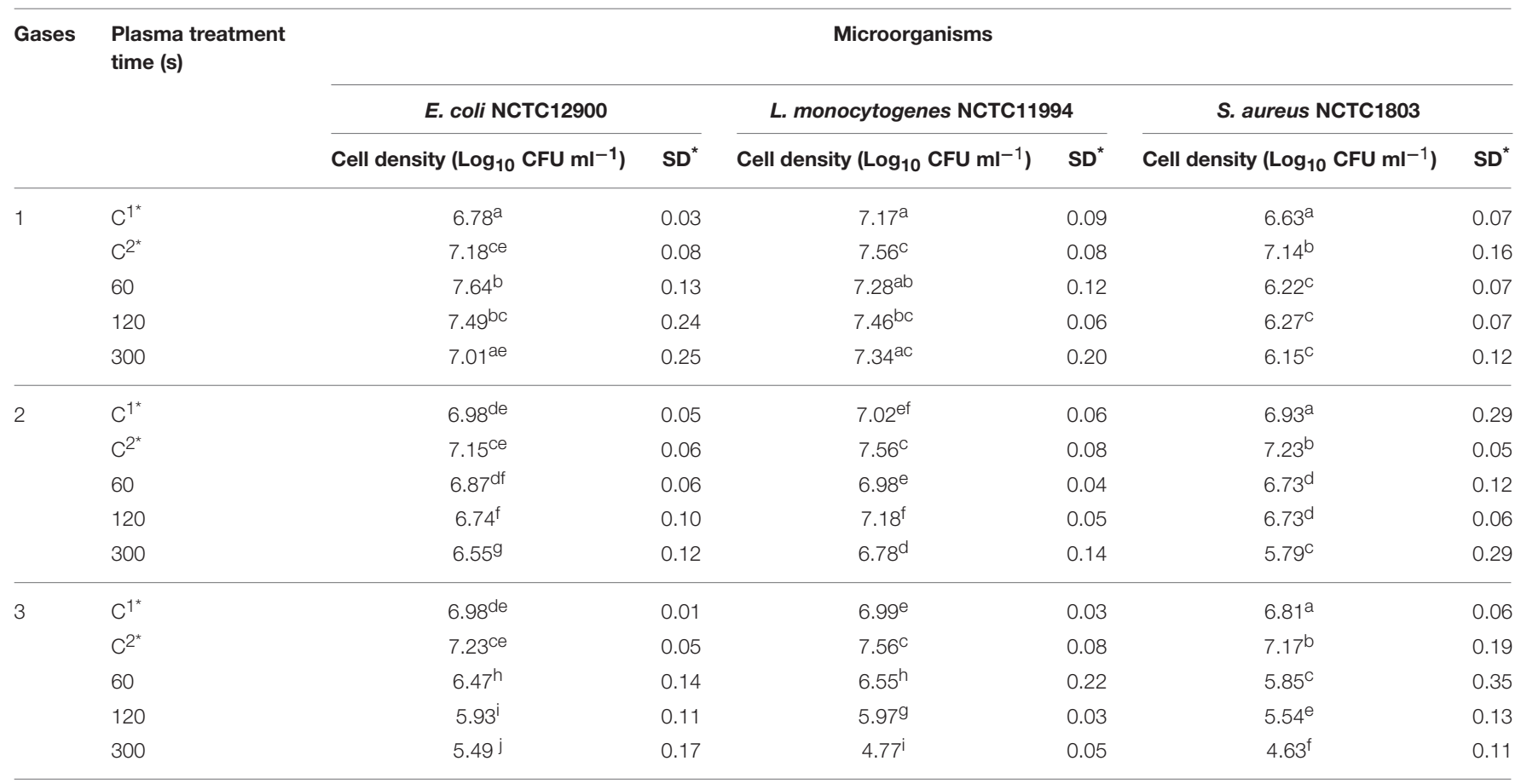

$S D^{*}$, standard deviation; $C^{1^{*}}$, Control without storage; $C^{2^{*}}$, Control with storage. Different letters indicate a significant difference at the 0.05 level between gas mix and treatment times. Gases: $130 \% \mathrm{CO}_{2}+70 \% \mathrm{~N}_{2} ; 2$ Air; $330 \% \mathrm{CO}_{2}+70 \% \mathrm{O}_{2}$.

achieved with the same treatment parameters (Figure 3). The different mechanisms of action of reactive species result from different cell envelope structures, which reflects the content of lipopolysaccharide and peptidoglycan in Gram negative and positive bacteria (Han et al., 2015). The ROS concentration detected revealed the ACP induced damage to target cells with interaction with the target cells and treatment media observed. Different inactivation efficacies were achieved using PBS and $\mathrm{BE}$, where strong protective effects were observed with the $\mathrm{BE}$ media (Tables 1-3). Because inactivation under the detection limit was not achieved, the high nutrient content in the $\mathrm{BE}$ enabled regrowth after treatment, particularly under temperature abuse conditions. Assessment of ROS showed that very low concentrations of ROS were available for contact with cells treated in the BE media (Figure 3) as components of the meat medium such as proteins are likely to scavenge many of the ACP generated reactive species and thus pose a protective effect against the antimicrobial action of the reactive species (Figure 5). However, there were minimal effects of BE percentage in terms of protection and recovery of the cells, and the presence of even $3 \% \mathrm{BE}$ indicated that the longer treatment time at the higher voltage level would be required to overcome the strong challenge to inactivation efficacy. Additionally, the results highlighted the importance of storage condition, with obvious difference from both control and treated samples under refrigerated and abuse temperature (Table 6). Refrigerated storage condition maintained the control samples at similar levels, while abuse temperature enhanced the growth significantly $(p<0.05)$. After ACP treatment, storage at $4^{\circ} \mathrm{C}$ maintained population densities at the reduced level, while the recovery at $37^{\circ} \mathrm{C}$ nullified the microbicidal effect. To assess the effect of ACP treatment following storage, a cell recovery modeling study was performed. The effect of environmental factors on the lag phase and growth rate of foodborne pathogens has been widely reported, including environmental $\mathrm{pH}$, osmolality, temperature and sterilization treatment (Mackey and Derrick, 1982; Robinson et al., 1998; Mellefont et al., 2003). In our study, the $\mu_{\max }$ was found to be ACP treatment time dependent, with E. coli showing more significant changes of $\mu_{\max }$ than the Gram positive bacteria. The cell damage caused by ACP treatment resulted in a longer recovery time during refrigerated storage. A similar trend is reported in Millan Sango et al. (2015) for E. coli. With this effect of temperature in the cell recovery model, refrigerated storage is recommended in combination with ACP treatment in developing industrial applications.

MAP is commonly used in the packaging of meat products to extend product quality and shelf-life. The efficacy of ACP treatment for inactivation of meat contaminants was therefore investigated not only in air but also in two modified atmospheres commonly used for packed meat products. The highest inactivation levels were achieved with high oxygen content gases (Tables 6, 7). The influence of gas composition on ACP treatment has been reported, where oxygen percentage played the most important role (Laroussi and Leipold, 2004; Han et al., 2014). At the same time, the generation of RNS has also been observed in air plasma (Price et al., 2013; Ziuzina et al., 2013; Moiseev et al., 2014; Jayasena et al., 2015), where joint effects of RNS with ROS lead to higher inactivation than either 


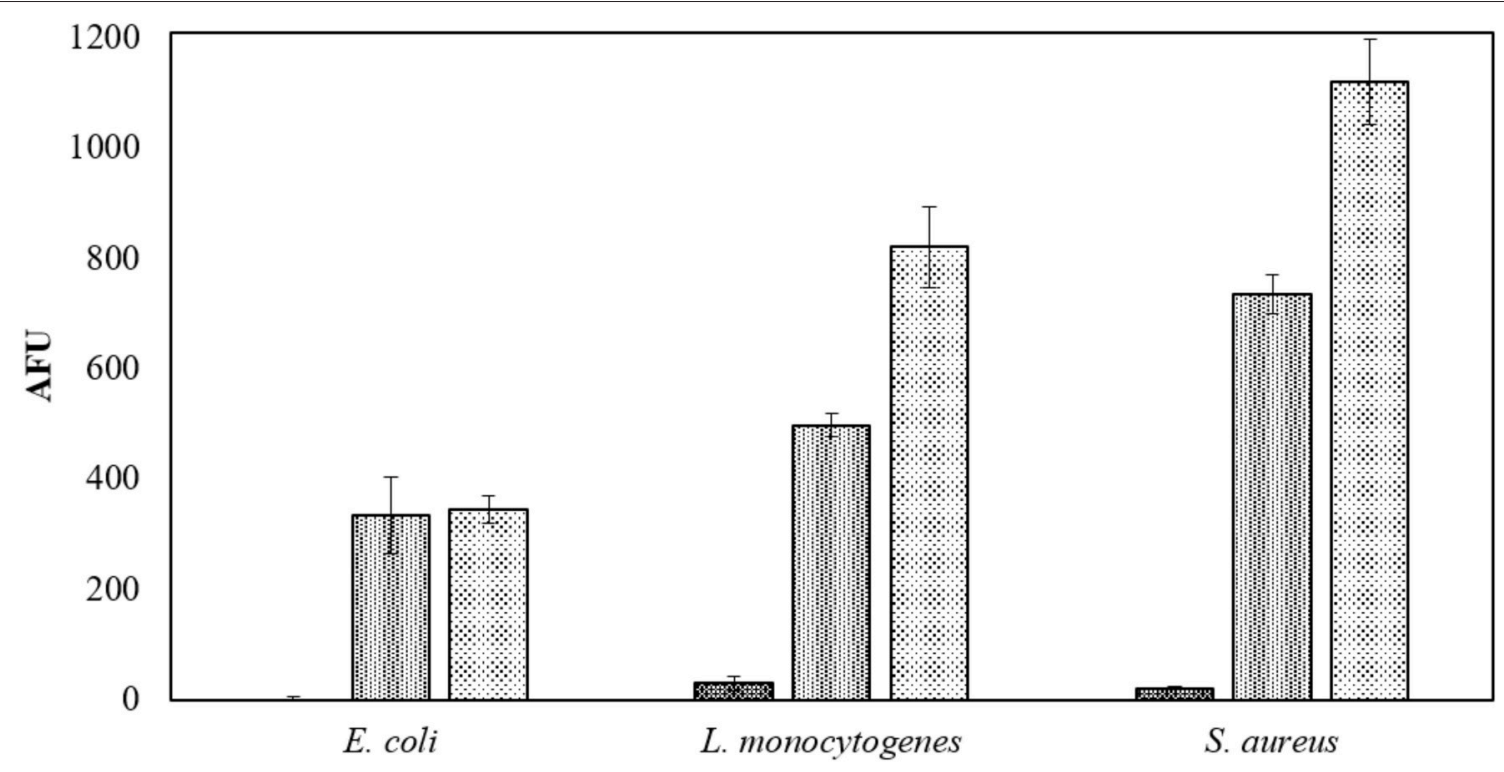

FIGURE 4 | Applied gases associated intracellular ROS density assay by DCFH DA. Samples in PBS treated for 60 s at $80 \mathrm{kV}$ RMS in applied gases: $30 \%$ $\mathrm{CO}_{2}+70 \% \mathrm{~N}_{2}$; ;

TABLE 8 | In-package ozone concentration with different MAP gases after different ACP treatment at $80 \mathbf{k V}_{\mathrm{RMS}}$.

\begin{tabular}{|c|c|c|c|c|c|c|}
\hline Plasma treatment time (s) & \multicolumn{6}{|c|}{ Ozone concentration (ppm) } \\
\hline 15 & $N D^{*}$ & $\mathrm{ND}^{*}$ & 533 & 231 & 1280 & 179 \\
\hline 30 & $N D^{*}$ & $\mathrm{ND}^{*}$ & 1067 & 493 & 5400 & 849 \\
\hline 60 & $N D^{*}$ & $\mathrm{ND}^{*}$ & 2450 & 496 & 12050 & 2375 \\
\hline 120 & $N D^{*}$ & $\mathrm{ND}^{*}$ & 2814 & 1619 & 12240 & 1951 \\
\hline
\end{tabular}

$S D^{*}$, standard deviation; $N D^{*}$, non-detectable.

group alone (Boxhammer et al., 2012). As the main mechanism of the joint effect, peroxynitrites have been fully discussed by ACP researchers as effective microbicidal species, generated through the secondary reactions of ACP generated ROS and RNS (Brisset and Hnatiuc, 2012; Lukes et al., 2014; Arjunan et al., 2015). Therefore, the use of a MAP gas combination that would mitigate the production of either ROS or RNS may not yield the best antimicrobial efficacy overall. A complete analysis of ROS and RNS generation and kinetics with this DBD system is detailed in Moiseev et al. (2014). A higher content of oxygen in MAP gas in this study led to a higher level of ROS generated, which improved the inactivation effect (Tables 6-8, Figure 4). The effect of ozone treatment of food quality has been widely evaluated, where the presence of ozone has promising decontamination effect for food product (Pérez et al., 1999; An et al., 2007). However, it could potentially damage food components, especially antioxidants in fresh-cut fruits and vegetables (Rico et al., 2007). Therefore, non-oxygen MAP gas might be an alternative choice for oxidative sensitive processing targets of ACP.
In this study, three meat pathogens were evaluated. S. aureus is well-known as a multi-resistant bacteria, however, its strong resistance was only observed in biofilm results here, with similar reductions to L. monocytogenes and E. coli in liquid (Tables 1-6). L. monocytogenes showed higher sensitivity than E. coli and $S$. aureus in PBS but equivalent survival in BE media, which indicates the more critical role of the nutrient environment and availability on protection or recovery. Among the parameters studied, the target properties, including planktonic or biofilm and nutritive composition in media, were crucial for ACP inactivation. While a strong interactive effect of treatment time and gas composition was observed from PBS planktonic models, the influence of these parameters were minimized by the protection of surface properties.

\section{CONCLUSION}

Overall, the process and system parameters of ACP treatments were found to govern the inactivation efficacy by generating 


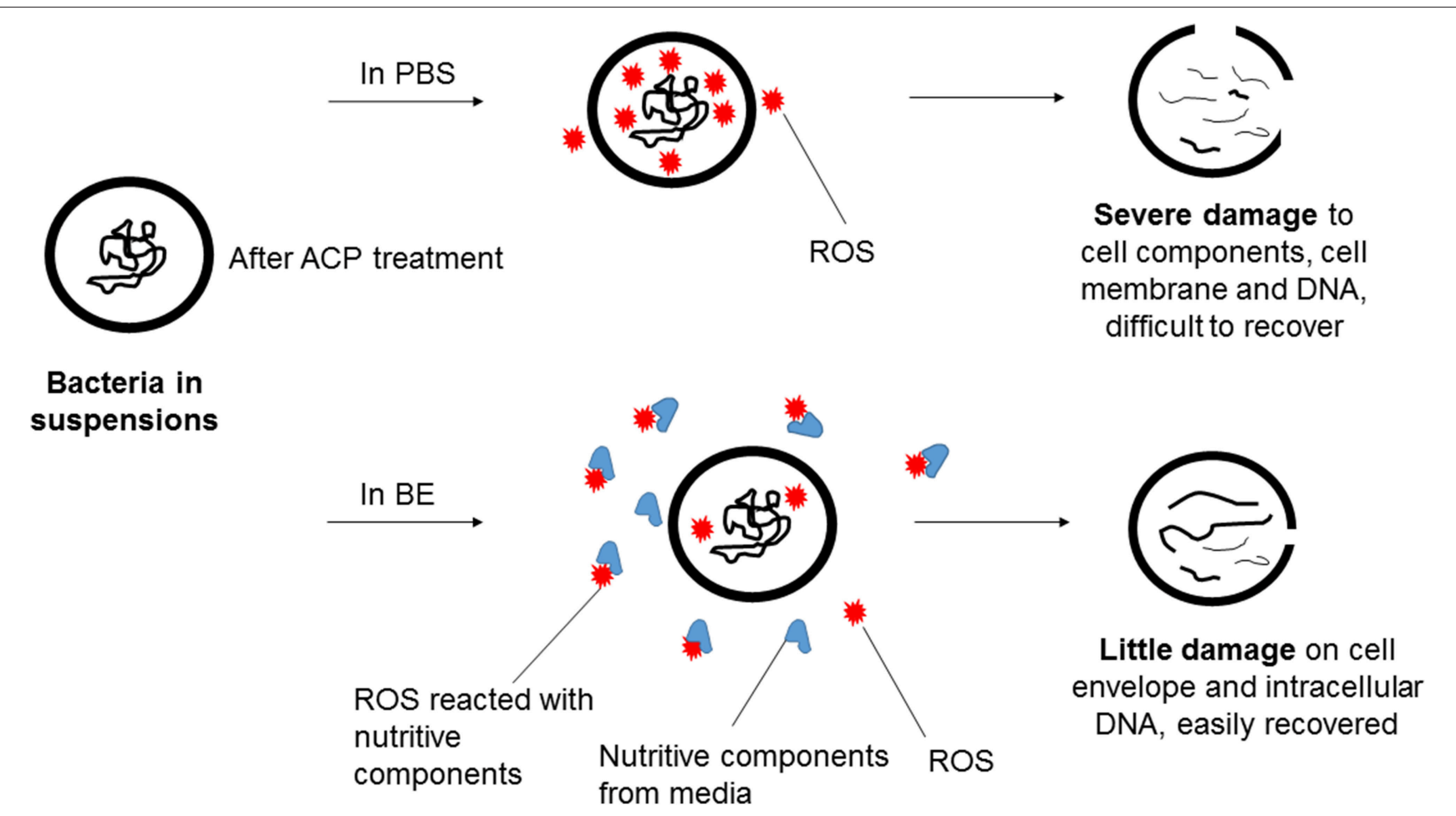

FIGURE 5 | Proposed mechanism of action of ACP generated ROS in bacteria suspensions of PBS and BE.

different amounts of reactive species. The nutrient content available at meat surfaces could provide protective effects against ACP treatment with reduced inactivation levels due to the decreased ROS levels. Moreover, Gram positive and negative bacteria showed significant differences in the quantities of ROS detected, implying different damaging patterns, although ACP had similar antimicrobial efficacy against both. Additionally, maintaining refrigerated storage temperature will maintain the microbial reductions achieved by ACP treatment. These results indicate both the potential and the limitations of the use of ACP for inactivation of microbiological challenges to meat safety and can help to develop and optimize treatment strategies. The further development of HV ACP for meat decontamination can be determined according to the characteristics of the biological

\section{REFERENCES}

An, J., Zhang, M., and Lu, Q. (2007). Changes in some quality indexes in fresh-cut green asparagus pretreated with aqueous ozone and subsequent modified atmosphere packaging. J. Food Eng. 78, 340-344. doi: 10.1016/j.jfoodeng.2005.10.001

Arjunan, K. P., Sharma, V. K., and Ptasinska, S. (2015). Effects of atmospheric pressure plasmas on isolated and cellular DNA-a review. Int. J. Mol. Sci. 16, 2971-3016. doi: 10.3390/ijms16022971

Basaran, P., Basaran-Akgul, N., and Oksuz, L. (2008). Elimination of Aspergillus parasiticus from nut surface with low pressure cold plasma (LPCP) treatment. Food Microbiol. 25, 626-632. doi: 10.1016/j.fm.2007.12.005 target, the matrix and/or surface characteristics in addition to equipment design.

\section{AUTHOR CONTRIBUTIONS}

PB, LH, VV, PC, and DB conceived and designed the experiments; $\mathrm{LH}, \mathrm{DZ}, \mathrm{DS}, \mathrm{CH}, \mathrm{AP}$ performed the experiments; $\mathrm{PB}, \mathrm{LH}, \mathrm{DB}$, $\mathrm{VV}, \mathrm{DS}$ wrote the paper.

\section{ACKNOWLEDGMENTS}

The research leading to these results has received funding from the European Community's Seventh Framework Program (FP7/SME-2013) under grant agreement number 605125.

Bayles, D. O., Annous, B. A., and Wilkinson, B. J. (1996). Cold stress proteins induced in Listeria monocytogenes in response to temperature downshock and growth at low temperatures. Appl. Environ. Microbiol. 62, 1116-1119.

Biesta-Peters, E. G., Reij, M. W., Joosten, H., Gorris, L. G., and Zwietering, M. H. (2010). Comparison of two optical-density-based methods and a plate count method for estimation of growth parameters of Bacillus cereus. Appl. Environ. Microbiol. 76, 1399-1405. doi: 10.1128/AEM.02336-09

Boxhammer, V., Morfill, G. E., Jokipii, J. R., Shimizu, T., Klämpfl, T., Li, Y. F., et al. (2012). Bactericidal action of cold atmospheric plasma in solution. New J. Phys. 14, 113042. doi: 10.1088/1367-2630/14/11/113042

Braoudaki, M., and Hilton, A. C. (2004). Low level of cross- resistance between triclosan and antibiotics in Escherichia coli $\mathrm{K}-12$ and E. coli $\mathrm{O} 55$ compared 
to E. coli O157. FEMS Microbiol. Lett. 235, 305-309. doi: 10.1111/j.15746968.2004.tb09603.x

Bridier, A., Sanchez-Vizuete, P., Guilbaud, M., Piard, J.-C., Naïtali, M., and Briandet, R. (2015). Biofilm-associated persistence of food-borne pathogens. Food Microbiol. 45, 167-178. doi: 10.1016/j.fm.2014.04.015

Brisset, J.-L., and Hnatiuc, E. (2012). Peroxynitrite: a re-examination of the chemical properties of non-thermal discharges burning in air over aqueous solutions. Plasma Chem. Plasma Process. 32, 655-674. doi: 10.1007/s11090-0129384-x

Brown, D. F. (2001). Detection of methicillin/oxacillin resistance in staphylococci. J. Antimicrob. Chemother. 48, 65-70. doi: 10.1093/jac/48.suppl_1.65

Chorianopoulos, N. (2012). "Biofilm vs. planktonic cells: a comparative study on cross-contamination levels of beef filets by the pathogenic bacteria Listeria monocytogenes, Escherichia coli O157: H7 and Salmonella enterica ser. Typhimurium," in 2012 IAFP Annual Meeting (Providence, RI).

Cuppers, H., and Smelt, J. (1993). Time to turbidity measurement as a tool for modeling spoilage by Lactobacillus. J. Ind. Microbiol. 12, 168-171. doi: 10.1007/BF01584186

Denny, J., and McLauchlin, J. (2008). Human Listeria monocytogenes infections in Europe - an opportunity for improved European surveillance. Euro Surveill. 13, 1854-1861.

Doyle, M., and Erickson, M. (2006). Reducing the carriage of foodborne pathogens in livestock and poultry. Poult. Sci. 85, 960-973. doi: 10.1093/ps/85.6.960

Ermolaeva, S. A., Varfolomeev, A. F., Chernukha, M. Y., Yurov, D. S., Vasiliev, M. M., Kaminskaya, A. A., et al. (2011). Bactericidal effects of non-thermal argon plasma in vitro, in biofilms and in the animal model of infected wounds. J. Med. Microbiol. 60, 75-83. doi: 10.1099/jmm.0.020263-0

Fernández, A., Noriega, E., and Thompson, A. (2013). Inactivation of Salmonella enterica serovar Typhimurium on fresh produce by cold atmospheric gas plasma technology. Food Microbiol. 33, 24-29. doi: 10.1016/j.fm.2012.08.007

Fernández, A., and Thompson, A. (2012). The inactivation of Salmonella by cold atmospheric plasma treatment. Food Res. Int. 45, 678-684. doi: 10.1016/j.foodres.2011.04.009

Giaouris, E., Heir, E., Hébraud, M., Chorianopoulos, N., Langsrud, S., Møretr,ø, T., et al. (2014). Attachment and biofilm formation by foodborne bacteria in meat processing environments: causes, implications, role of bacterial interactions and control by alternative novel methods. Meat Sci. 97, 298-309. doi: 10.1016/j.meatsci.2013.05.023

Gomes, A., Fernandes, E., and Lima, J. L. F. C. (2005). Fluorescence probes used for detection of reactive oxygen species. J. Biochem. Biophys. Methods 65, 45-80. doi: 10.1016/j.jbbm.2005.10.003

Han, L., Patil, S., Boehm, D., Milosavljeviæ, V., Cullen, P., and Bourke, P. (2015). Mechanism of inactivation by high voltage atmospheric cold plasma differs between Escherichia coli and Staphylococcus aureus. Appl. Environ. Microbiol. 82, 450-458. doi: 10.1128/AEM.02660-15

Han, L., Patil, S., Keener, K. M., Cullen, P. J., and Bourke, P. (2014). Bacterial inactivation by high-voltage atmospheric cold plasma: influence of process parameters and effects on cell leakage and DNA damage. J. Appl. Microbiol. 116, 784-794. doi: 10.1111/jam.12426

Jayasena, D. D., Kim, H. J., Yong, H. I., Park, S., Kim, K., Choe, W., et al. (2015). Flexible thin-layer dielectric barrier discharge plasma treatment of pork butt and beef loin: effects on pathogen inactivation and meat-quality attributes. Food Microbiol. 46, 51-57. doi: 10.1016/j.fm.2014.07.009

Joshi, S. G., Cooper, M., Yost, A., Paff, M., Ercan, U. K., Fridman, G., et al. (2011). Nonthermal dielectric-barrier discharge plasma-induced inactivation involves oxidative DNA damage and membrane lipid peroxidation in Escherichia coli. Antimicrob. Agents Chemother. 55, 1053-1062. doi: 10.1128/AAC.01002-10

Kayes, M. M., Critzer, F. J., Kelly-Wintenberg, K., Roth, J. R., Montie, T. C., and Golden, D. A. (2007). Inactivation of foodborne pathogens using a one atmosphere uniform glow discharge plasma. Foodborne Pathog. Dis. 4, 50-59. doi: $10.1089 /$ fpd.2006.62

Kerry, J., O'Grady, M., and Hogan, S. (2006). Past, current and potential utilisation of active and intelligent packaging systems for meat and muscle-based products: a review. Meat Sci. 74, 113-130. doi: 10.1016/j.meatsci.2006.04.024

Klämpfl, T. G., Isbary, G., Shimizu, T., Li, Y.-F., Zimmermann, J. L., Stolz, W., et al. (2012). Cold atmospheric air plasma sterilization against spores and other microorganisms of clinical interest. Appl. Environ. Microb. 78, 5077-5082. doi: 10.1128/AEM.00583-12
Lacombe, A., Niemira, B. A., Gurtler, J. B., Fan, X., Sites, J., Boyd, G., et al. (2015). Atmospheric cold plasma inactivation of aerobic microorganisms on blueberries and effects on quality attributes. Food Microbiol. 46, 479-484. doi: 10.1016/j.fm.2014.09.010

Laroussi, M., and Leipold, F. (2004). Evaluation of the roles of reactive species, heat, and UV radiation in the inactivation of bacterial cells by air plasmas at atmospheric pressure. Int. J. Mass Spectrom. 233, 81-86. doi: 10.1016/j.ijms.2003.11.016

Laroussi, M., Mendis, D. A., and Rosenberg, M. (2003). Plasma interaction with microbes. New J. Phys. 5, 41.1-41.10. doi: 10.1088/1367-2630/5/ $1 / 341$

Le Loir, Y., Baron, F., and Gautier, M. (2003). Staphylococcus aureus and food poisoning. Genet. Mol. Res. 2, 63-76.

Liang, Y., Wu, Y., Sun, K., Chen, Q., Shen, F., Zhang, J., et al. (2012). Rapid inactivation of biological species in the air using atmospheric pressure nonthermal plasma. Environ. Sci. Technol. 46, 3360-3368. doi: $10.1021 /$ es203770q

Lukes, P., Dolezalova, E., Sisrova, I., and Clupek, M. (2014). Aqueousphase chemistry and bactericidal effects from an air discharge plasma in contact with water: evidence for the formation of peroxynitrite through a pseudo-second-order post-discharge reaction of $\mathrm{H} 2 \mathrm{O} 2$ and $\mathrm{HNO} 2$. Plasma Sourc. Sci. Technol. 23:015019. doi: 10.1088/0963-0252/23/1/ 015019

Lund, M. N., Lametsch, R., Hviid, M. S., Jensen, O. N., and Skibsted, L. H. (2007). High-oxygen packaging atmosphere influences protein oxidation and tenderness of porcine Longissimus dorsi during chill storage. Meat Sci. 77, 295-303. doi: 10.1016/j.meatsci.2007.03.016

Mackey, B. M., and Derrick, C. M. (1982). The effect of sublethal injury by heating, freezing, drying and gamma-radiation on the duration of the lag phase of Salmonella typhimurium. J. Appl. Bacteriol. 53, 243-251. doi: 10.1111/j.13652672.1982.tb04683.x

Mellefont, L., McMeekin, T., and Ross, T. (2003). The effect of abrupt osmotic shifts on the lag phase duration of foodborne bacteria. Int. J. Food Microbiol. 83, 281-293. doi: 10.1016/S0168-1605(02)00377-X

Miao, H., and Yun, G. (2011). The sterilization of Escherichia coli by dielectricbarrier discharge plasma at atmospheric pressure. Appl. Surf. Sci. 257, 7065-7070. doi: 10.1016/j.apsusc.2011.03.014

Millan Sango, D., Han, L., Milosavljevic, V., Van Impe, J. F., Bourke, P., Cullen, P. J., et al. (2015). Assessing bacterial recovery and efficacy of cold atmospheric plasma treatments. Food Bioprod. Process 96, 154-460. doi: 10.1016/j.fbp.2015.07.011

Misra, N. N., Moiseev, T., Patil, S., Pankaj, S. K., Bourke, P., Mosnier, J. P., et al. (2014). Cold plasma in modified atmospheres for post-harvest treatment of strawberries. Food Bioprocess Technol. 7, 3045-3054. doi: 10.1007/s11947-014-1 356-0

Moiseev, T., Misra, N., Patil, S., Cullen, P., Bourke, P., Keener, K., et al. (2014). Post-discharge gas composition of a large-gap DBD in humid air by UVVis absorption spectroscopy. Plasma Sourc. Sci. Technol. 23:065033. doi: 10.1088/0963-0252/23/6/065033

Montie, T. C., Kelly-Wintenberg, K., and Reece Roth, J. (2000). An overview of research using the one atmosphere uniform glow discharge plasma (OAUGDP) for sterilization of surfaces and materials. Plasma Sci. IEEE Trans. 28, 41-50. doi: 10.1109/27.842860

Niemira, B. A., Boyd, G., and Sites, J. (2014). Cold plasma rapid decontamination of food contact surfaces contaminated with Salmonella biofilms. J. Food Sci. 79, M917-M922. doi: 10.1111/1750-3841.12379

Okayama, T., Muguruma, M., Murakami, S., and Yamada, H. (1995). Studies on modified atmosphere packaging of thin sliced beef, 1: effect of two modified atmosphere packaging systems on $\mathrm{pH}$ value, microbial growth, metmyoglobin formation and lipid oxidation of thin sliced beef. J. Jpn. Soc. Food Sci. Technol. 42, 498-504. doi: 10.3136/nskkk.42.498

Pankaj, S., Misra, N., and Cullen, P. (2013). Kinetics of tomato peroxidase inactivation by atmospheric pressure cold plasma based on dielectric barrier discharge. Innov. Food Sci. Emerg. Technol. 19, 153-157. doi: 10.1016/j.ifset.2013.03.001

Pérez, A. G., Sanz, C., Ríos, J. J., Olias, R., and Olías, J. M. (1999). Effects of ozone treatment on postharvest strawberry quality. J. Agric. Food Chem. 47, 1652-1656. doi: 10.1021/jf980829l 
Price, R. O., Chiavarini, R., Kolb, J. F., and Schoenbach, K. H. (2013). Cold air atmospheric pressure micro plasma jet application method and device. Google Patents.

Rico, D., Martin-Diana, A. B., Barat, J., and Barry-Ryan, C. (2007). Extending and measuring the quality of fresh-cut fruit and vegetables: a review. Trends Food Sci. Technol. 18, 373-386. doi: 10.1016/j.tifs.2007.03.011

Robinson, T. P., Ocio, M. J., Kaloti, A., and Mackey, B. M. (1998). The effect of the growth environment on the lag phase of Listeria monocytogenes. Int. J. Food Microbiol. 44, 83-92. doi: 10.1016/S0168-1605(98)00120-2

Rød, S. K., Hansen, F., Leipold, F., and Knøchel, S. (2012). Cold atmospheric pressure plasma treatment of ready-to-eat meat: inactivation of Listeria innocua and changes in product quality. Food Microbiol. 30, 233-238. doi: 10.1016/j.fm.2011.12.018

Sivertsvik, M., Rosnes, J., and Bergslien, H. (2002). "Modified atmosphere packaging," in Minimal Processing Technologies in the Food Industry, eds T. Ohlsson and N. Bengtsson (Stavanger: Woodhead Publishing Limited; CRC Press), 61-86.

Smiddy, M., Papkovsky, D., and Kerry, J. (2002). Evaluation of oxygen content in commercial modified atmosphere packs (MAP) of processed cooked meats. Food Res. Int. 35, 571-575. doi: 10.1016/S0963-9969(01)00159-4

Sofos, J. N., and Geornaras, I. (2010). Overview of current meat hygiene and safety risks and summary of recent studies on biofilms, and control of Escherichia coli O157: H7 in nonintact, and Listeria monocytogenes in ready-to-eat, meat products. Meat Sci. 86, 2-14. doi: 10.1016/j.meatsci.2010.04.015

Sørheim, O., Nissen, H., and Nesbakken, T. (1999). The storage life of beef and pork packaged in an atmosphere with low carbon monoxide and high carbon dioxide. Meat Sci. 52, 157-164. doi: 10.1016/S0309-1740(98)00163-6

Tang, Q., Jiang, W., Cheng, Y., Lin, S., Lim, T., and Xiong, J. (2011). Generation of reactive species by gas-phase dielectric barrier discharges. Ind. Eng. Chem. Res. 50, 9839-9846. doi: 10.1021/ie200039w

Yong, H. I., Kim, H.-J., Park, S., Alahakoon, A. U., Kim, K., Choe, W., et al. (2015). Evaluation of pathogen inactivation on sliced cheese induced by encapsulated atmospheric pressure dielectric barrier discharge plasma. Food Microbiol. 46, 46-50. doi: 10.1016/j.fm.2014.07.010

Yu, H., Perni, S., Shi, J., Wang, D., Kong, M., and Shama, G. (2006). Effects of cell surface loading and phase of growth in cold atmospheric gas plasma inactivation of Escherichia coli K12. J. Appl. Microbiol. 101, 1323-1330. doi: 10.1111/j.1365-2672.2006.03033.x

Yun, H., Kim, B., Jung, S., Kruk, Z. A., Kim, D. B., Choe, W., et al. (2010). Inactivation of Listeria monocytogenes inoculated on disposable plastic tray, aluminum foil, and paper cup by atmospheric pressure plasma. Food Control 21, 1182-1186. doi: 10.1016/j.foodcont.2010. 02.002

Ziuzina, D., Patil, S., Cullen, P. J., Keener, K. M., and Bourke, P. (2013). Atmospheric cold plasma inactivation of Escherichia coli in liquid media inside a sealed package. J. Appl. Microbiol. 114, 778-787. doi: 10.1111/jam. 12087

Ziuzina, D., Patil, S., Cullen, P. J., Keener, K. M., and Bourke, P. (2014). Atmospheric cold plasma inactivation of Escherichia coli, Salmonella enterica serovar Typhimurium and Listeria monocytogenes inoculated on fresh produce. Food Microbiol. 42, 109-116. doi: 10.1016/j.fm.2014. 02.007

Conflict of Interest Statement: The authors declare that the research was conducted in the absence of any commercial or financial relationships that could be construed as a potential conflict of interest.

Copyright (c) 2016 Han, Ziuzina, Heslin, Boehm, Patange, Sango, Valdramidis, Cullen and Bourke. This is an open-access article distributed under the terms of the Creative Commons Attribution License (CC BY). The use, distribution or reproduction in other forums is permitted, provided the original author (s) or licensor are credited and that the original publication in this journal is cited, in accordance with accepted academic practice. No use, distribution or reproduction is permitted which does not comply with these terms. 